\title{
ENERGY-EFFICIENT GAS-TURBINE BLADE-MATERIAL TECHNOLOGY - A REVIEW
}

\author{
TEHNOLOGIJA MATERIALOV LOPATIC ENERGETSKO \\ UČINKOVITIH PLINSKIH TURBIN - PREGLED
}

\author{
Zainul Huda \\ King Abdulaziz University, Department of Mechanical Engineering, Jeddah 21589, Saudi Arabia \\ drzainulhuda@hotmail.com \\ Prejem rokopisa - received: 2015-07-03; sprejem za objavo - accepted for publication: 2016-02-29
}

doi: $10.17222 /$ mit.2015.196

\begin{abstract}
Energy-efficient gas turbines (GTs) with reduced emissions have significantly contributed to sustainable development. However, these advanced engines, operating at turbine inlet temperatures (TITs) as high as $1.600{ }^{\circ} \mathrm{C}$, require the development of highly creep-resistant materials for application in hotter-section components of GTs. This paper first reviews recent advancements in the development of creep-resistant superalloys and their microstructural control, including stable gamma-prime raft structures. Then a comparative analysis of recently developed SC superalloys is presented to enable GT designers to select appropriate materials for hotter energy-efficient GT engines. It is recommended to develop new creep-limited alloys based on the metals with higher melting temperatures (e.g., Mo and $\mathrm{Nb}$ alloyed with silicon); these future alloys are proposed as prospective candidates for hotter energy-efficient GTs.

Keywords: energy-efficient gas turbines, gas-turbine blades, turbine inlet temperature, single-crystal superalloys
\end{abstract}

Energetsko učinkovite plinske turbine (angl. GT) z zmanjšanimi emisijami so močno prispevale pri trajnostnem razvoju. Vendar pa ti napredni stroji, ki delujejo pri temperaturah do $1600{ }^{\circ} \mathrm{C}$ v vstopnem delu turbine zahtevajo, za uporabo komponent v vročem delu, razvoj materialov odpornih na lezenje. Clanek predstavlja prvi pregled trenutnega napredka pri razvoju na lezenje odpornih superzlitin in kontrolo njihovih mikrostruktur, vključno s stabilno zgradbo gama-prime. Predstavljena je analiza pred kratkim razvitih SC superzlitin, tako da je konstrukterjem GT omogočena izbira primernega materiala za bolj vroče, energijsko učinkovite GT stroje. Predlagan je razvoj novih zlitin z omejenim lezenjem, ki temeljijo na kovinah $\mathrm{z}$ višjo temperature tališča (npr. Mo in Nb legiran s silicijem); te bodoče zlitine so predlagane kot perspektivne za bolj vroče, energijsko učinkovite GT.

Ključne besede: energijsko učinkovite plinske turbine, lopatice plinskih turbin, vhodna temperatura turbine, monokristalne superzlitine

\section{INTRODUCTION}

Modern combined cycle gas-turbine (CCGT) engines require a significant increase of turbine inlet temperatures (TIT) for achieving the maximum efficiency. ${ }^{1-2}$ This thermodynamic trend resulted in an increased service temperature, enhanced creep damage and hot-corrosion attack of the hotter-engine materials. ${ }^{3-4}$ In particular, the gas-turbine (GT) blades operate under the most arduous conditions of temperature and stress of any component in the engine. Nickel-based superalloys exhibit an excellent high-temperature creep resistance, thermal stability, good tensile strength, long fatigue life, microstructural stability at a high temperature as well as good resistances to oxidation and hot corrosion..$^{5-6}$ For these reasons, they are used in the manufacturing of gas turbine hot-section components. ${ }^{7-8}$

In order to enable energy-efficient gas turbines to operate at higher TITs, modern CCGTs including advanced single-crystal (SC) superalloys and special thermal-barrier coatings (TBCs) should be used..$^{9-10}$ The thermal efficiency of such advanced engines involving closed-loop steam cooling may reach more than $60 \%$.
The operating temperatures in the first-stage and second-stage SC blades of modern CCGTs lie in ranges of $1300-1500{ }^{\circ} \mathrm{C}$ and $1000-1100{ }^{\circ} \mathrm{C}$, respectively. For example, General Electric (GE) Inc., producing USA H turbines, uses SC materials for first-stage blades and vanes that operate at a temperature of $1430{ }^{\circ} \mathrm{C}$. Similarly, first-stage turbine blades of Siemens SGT5-8000H machines are made of specialized high-temperature alloy material to combat the long-term effects of high temperatures at a constant stress (to resist creep deformation).

\section{GT-BLADE-MATERIAL TECHNOLOGY}

Materials for hot-section components of hotter GT engines are subjected to very hard operating conditions. The GT blades, having their walls only a millimeter thick, whizz around at about $10.000 \mathrm{~min}^{-1}$, while gases pass across their surface at over $1500{ }^{\circ} \mathrm{C}$. The GT-bladematerial technology progressed in two fronts:

1) GT-blade alloys,

2) thermal barrier coatings (TBCs).

This progress is reviewed in the following subsections. 
Table 1: Chemical compositions of two GT-blade superalloys Tabela 1: Kemijska sestava dveh superzlitin za lopatice GT

\begin{tabular}{|c|c|c|c|c|c|c|c|c|c|c|c|c|}
\hline Superalloy & $\% \mathrm{Cr}$ & $\% \mathrm{Co}$ & $\% \mathrm{Ti}$ & $\% \mathrm{~W}$ & $\% \mathrm{Al}$ & $\% \mathrm{Ta}$ & $\% \mathrm{Mo}$ & $\% \mathrm{Fe}$ & $\% \mathrm{C}$ & $\% \mathrm{~B}$ & $\% \mathrm{Cb}$ & $\% \mathrm{Ni}$ \\
\hline GTD-111 & 13.5 & 9.5 & 4.75 & 3.8 & 3.3 & 2.7 & 1.53 & 0.23 & 0.09 & 0.01 & - & balance \\
\hline Allvac $^{\circledR} 718$ Plus & 17.9 & 9 & 0.74 & 1.04 & 1.5 & - & 2.68 & 9.3 & 0.02 & 0.003 & 5.51 & balance \\
\hline
\end{tabular}

\subsection{GT-blade-alloy development}

It was established in the preceding section that besides the other important alloy characteristics, the hightemperature creep resistance is the primary requirement for the superalloy GT blades of hotter GT engines. The high-temperature creep strength of the superalloy GT blades is ensured by the precipitation of a high volume fraction of fine $\gamma$ ' particles in the material microstructure. ${ }^{711-12}$ Design principles for developing creep-limited alloys for the hot sections (particularly blades) of gas turbines were reported elsewhere. ${ }^{10,13}$

A number of advanced superalloys have been developed for GT blades during the recent two decades; these include single crystal (SC) superalloys (AM1, Rene N6, MC538, etc), the GTD-111 superalloy, directionally solidified (DS) GTD-111, the Allvac 718Plus superalloy and the like. ${ }^{14-18}$ The IN-738 superalloy remained in use for the first-stage blades of GT engines during 1971-1984. However, with the development of the GTD-111 superalloy, IN-738 has now become the stage-2 blade material. ${ }^{19}$ A comparative analysis of the performance of various SC alloys is presented in Section 4 , whereas the performance of equiaxed superalloys are discussed in the following section.

\subsection{TBC developments}

Thermal barrier coatings (TBCs) play a significant role in enhancing the energy efficiency since they enable gas turbines to be operated at higher turbine inlet temperatures (TIT). A TBC is a multi-layer coating consisting of the top coat (ceramic) and the inner layer (the bond coat) between the ceramic and the substrate. ${ }^{20-21}$ Recently, R. Kitazawa et al. ${ }^{22}$ have reported that a temperature gradient of $150{ }^{\circ} \mathrm{C}$ can be achieved using a ceramic TBC $\left(\mathrm{Y}_{2} \mathrm{O}_{3}-\mathrm{ZrO}_{2}\right.$ top coat $)$ on superalloy components.

Research on the TBC (bond coating) of the GT blades at Siemens Inc. resulted in a significant improvement in the long-life reliability of turbine blades. ${ }^{23}$ It was reported that adding 1-2\% of rhenium (a rare metal with a high melting temperature and a high density) to a mixture of cobalt, nickel, chromium, aluminum and yttrium (the so-called MCrAlY bond coatings) imbues the complex mixture with extraordinary properties. The rhenium improves the mechanical properties of the protective coating and simultaneously prevents the aluminum from diffusing into the base material. The coating system $(300-\mu m$-thick bond coating applied directly on the metal and a thin ceramic layer placed on the top) stops the base material from oxidizing. Without this coating system, the nickel-based alloy in the blade would only survive $4.000 \mathrm{~h}$ of operation at the maximum operating temperatures. With the coating, however, the alloy can hold out against the oxygen for more than $25.000 \mathrm{~h}$, longer than power-plant operators require as the minimum. ${ }^{23}$

\section{RECENTLY-DEVELOPED EQUI-AXED GT-BLADE SUPERALLOYS}

Although a number of superalloys have been developed for GTs, the GTD-111 and the Allvac 718Plus are the two notable equiaxed superalloys developed for the GT-blade application in recent years. The effects of the composition and the heat treatment on the microstructures and performance of the two GT blade superalloys are discussed in the following sub-sections.

\subsection{GTD-111 superalloy}

The GTD-111 superalloy is employed in manufacturing of the first-stage blades of high-power gas turbines. The chemical composition of the GTD-111 superalloy is presented in Table 1. The high aluminum and titanium contents ensure the precipitation of a high volume fraction of the $\gamma$ ' particles in the microstructure promoting a good creep strength.

The GTD-111 superalloy has a multiphase structure consisting of the $\gamma$ matrix, $\gamma^{\prime}$ precipitate, carbide, $\gamma-\gamma$ ' eutectic and a small amount of deleterious phases (e.g., $\delta, \eta, \sigma$, Laves). ${ }^{15,} 16$ The superalloy maintains a fairly

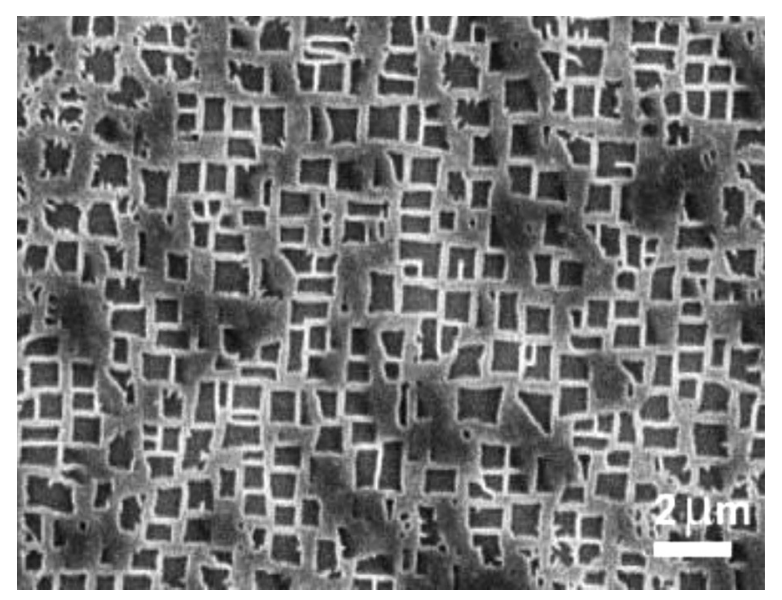

Figure 1: SEM micrograph showing the primary $\gamma$ ' in the heat-treated GTD-111 superalloy ${ }^{16}$

Slika 1: SEM-posnetek primarnih $\gamma^{\prime} \mathrm{v}$ toplotno obdelani GTD-111 superzlitini ${ }^{16}$ 


\section{Z. HUDA: ENERGY-EFFICIENT GAS-TURBINE BLADE-MATERIAL TECHNOLOGY - A REVIEW}

good tensile-yield strength of $780 \mathrm{MPa}$ with a $10 \%$ elongation at $700{ }^{\circ} \mathrm{C}^{24}$ (Table 2). Figure 1 shows the as-standard heat-treated microstructure of GTD-111. ${ }^{17}$

The alloy obtains its high-temperature creep strength mainly through the $\gamma^{\prime}$ precipitates that are present with a volume fraction $>60 \%$. The primary $\gamma^{\prime}$ particles have a cubic shape with the average edge of $0.8 \mu \mathrm{m}$. The fine spherical $\gamma^{\prime}$ particles precipitated during the aging treatment have the average diameter of $\approx 0.1 \mu \mathrm{m}$. The serrated grain boundaries increase the creep life and creep plasticity.

\subsection{Allvac $^{\circledR} 718$ Plus $^{\mathrm{TM}}$ superalloy}

Recently, a new 718Plus nickel-based superalloy has been developed for the application in energy-efficient gas-turbine engines allowing an increase in the TIT to a considerable degree for a high power output. Allvac ${ }^{\circledR}$ 718 Plus $^{\mathrm{TM}}$ is a novel nickel-based superalloy, designed for heavy-duty applications in energy-efficient gas turbines. ${ }^{18}$

The Allvac ${ }^{\circledR} 718$ Plus ${ }^{\mathrm{TM}}$ alloy contains nanometersized spherical $\gamma$ '-phase precipitates $\left(\mathrm{Ni}_{3}(\mathrm{Al}, \mathrm{Ti})\right)$ and plate-shaped $\delta$-phase precipitates $\left(\mathrm{Ni}_{3} \mathrm{Nb}\right)$ of a micrometer size (Figure 2). The chemical composition of the Allvac $^{\circledR}$ 718Plus ${ }^{\mathrm{TM}}$ superalloy shows higher chromium (Cr) and molybdenum (Mo) contents as compared to the GTD superalloy (Table 1). An exceptional feature in the composition of the Allvac ${ }^{\circledR} 718$ Plus $^{\mathrm{TM}}$ alloy is its good columbium $(\mathrm{Cb})$ content (which is absent in the GTD alloy). The high $\mathrm{Cb}$ content restricts the coarsening of the $\gamma$ ' particles in the superalloy microstructure ensuring a long-time creep resistance so as to allow an operation of a GT engine at a high temperature for longer periods of time. ${ }^{7,12} \mathrm{~A}$ transmission electron micrograph of the Allvac ${ }^{\circledR} 718$ Plus ${ }^{\mathrm{TM}}$ superalloy produced after the aging at $1148 \mathrm{~K}$ for $7800 \mathrm{~s}$ shows spherical precipitates of the $\gamma^{\prime}$ phase in the $\gamma$ matrix (Figure 2). The aging heat

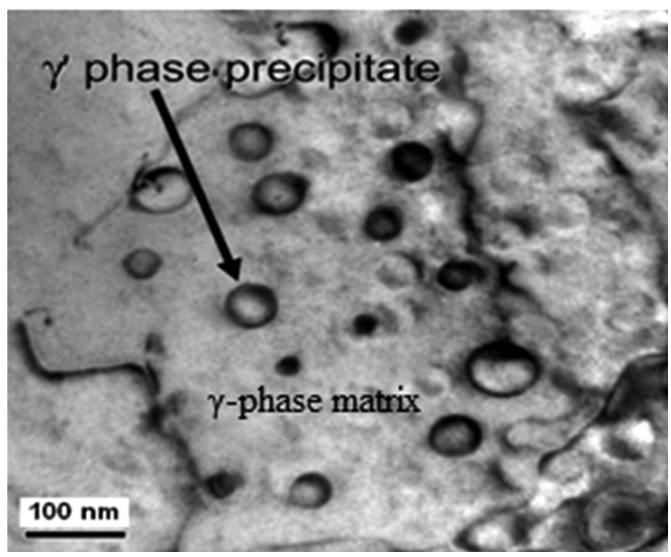

Figure 2: TEM image of superalloy Allvac $₫ 718$ Plus ${ }^{\mathrm{TM}}$ after aging at $1148 \mathrm{~K}$ for $7800 \mathrm{~s}^{17}$

Slika 2: TEM-posnetek superzlitine Allvac ${ }^{\circledR} 718$ Plus $^{\mathrm{TM}}$, po staranju $7800 \mathrm{~s}$ na $1148 \mathrm{~K}^{17}$ treatments of the superalloy lead to the precipitation of intermetallic phases. ${ }^{18}$

ATI Allvac ${ }^{\circledR}$ has excellent tensile properties at 700 ${ }^{\circ} \mathrm{C}^{25}$, i.e., $\sigma_{\mathrm{y}}=1014 \mathrm{MPa}$ and $\%$ elongation $=25$ (Table 2). It has a comparable tensile strength with a $55^{\circ} \mathrm{C}$ temperature advantage over the 718 alloy. It has higher tensile and creep strengths than Waspaloy and a comparable thermal stability up to at least $704^{\circ} \mathrm{C}$. Because of its good process and metallurgical flexibility, the 718Plus alloy provides opportunities for special processing such as fine-grain, mini-grain and superplastic forming, direct age forging, casting and for large ingot capability. ${ }^{25}$

Table 2: Tensile-yield strength at $700{ }^{\circ} \mathrm{C}$ for three typical GT-blade superalloys ${ }^{14,24}$

Tabela 2: Natezna meja plastičnosti pri $700{ }^{\circ} \mathrm{C}$, treh značilnih lopatic iz superzlitine za GT ${ }^{14,24}$

\begin{tabular}{|c|c|c|c|}
\hline Superalloy & $\begin{array}{c}\text { SC superalloy: } \\
\text { AMI }\end{array}$ & GTD-111 & $\begin{array}{c}\text { Allvac }^{\circledR} \\
718 \mathrm{Plus}^{\mathrm{TM}}\end{array}$ \\
\hline Yield strength & $1.550 \mathrm{MPa}$ & $780 \mathrm{MPa}$ & $1014 \mathrm{MPa}$ \\
\hline
\end{tabular}

\section{SINGLE-CRYSTAL GT-BLADE SUPERALLOYS}

The use of high-pressure turbine blades made of single-crystal (SC) nickel-based superalloys contributes efficiently to the continuous performance improvement of GT engines in terms of power and thermal efficiency. The employment of directional-solidification (DS) metallurgy enables us to manufacture single-crystal (SC) superalloy GT blades with an increased creep resistance (Figure 3).

SC superalloys have a two-phase microstructure consisting of $\gamma^{\prime}$ precipitates coherently embedded in the $\gamma$-phase matrix as the basic feature (Figure 4), which allows the outstanding creep resistance of nickel-based superalloys. Figure 4 shows a transmission-electron micrograph of a standard heat-treated SC superalloy with

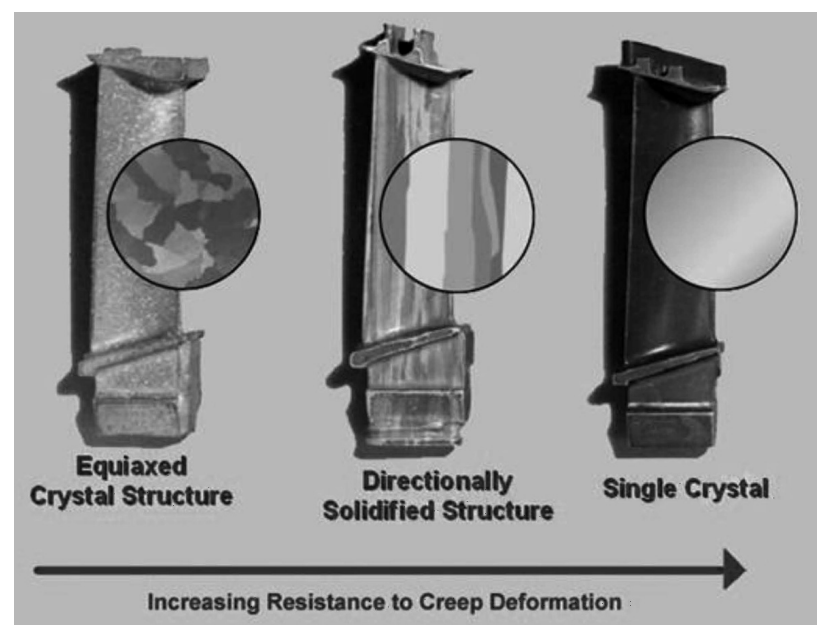

Figure 3: Crystal growth in [001] direction during solidification of a SC-superalloy blade

Slika 3: Rast kristalnih zrn v smeri [001] med strjevanjem lopatice iz SC-superzlitine 


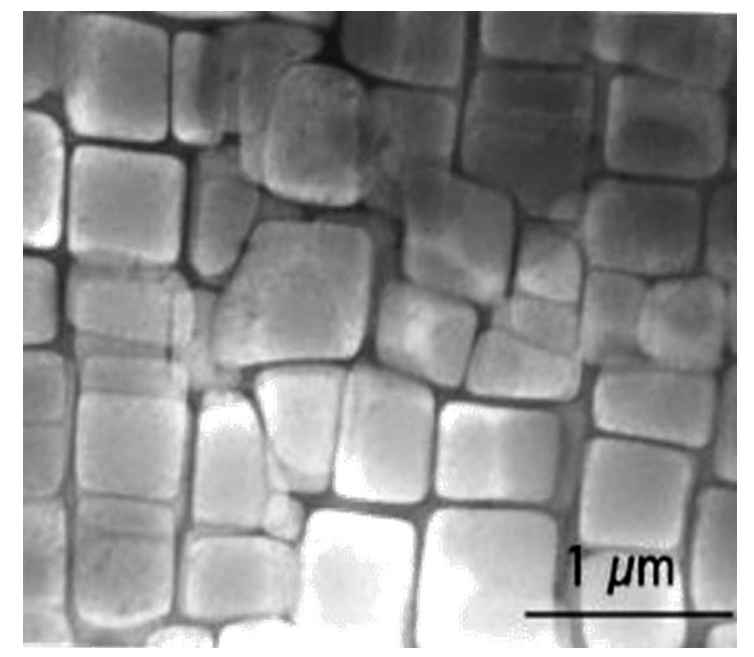

Figure 4: TEM micrograph showing a large volume fraction of cuboidal $\gamma$ ' particles in a $\gamma$ matrix of a SC superalloy: Ni-9.7Al-1.7Ti17.1Cr-6.3Co-2.3W \% of amount fractions

Slika 4: TEM-posnetek kaže velik delež kockastih delcev $\gamma^{\prime}$ v $\gamma$ osnovi superzlitine: Ni-9.7Al-1.7Ti-17.1Cr-6.3Co-2.3W atomskih \%

a composition of Ni-9.7Al-1.7Ti-17.1Cr-6.3Co-2.3W \% of the amount fractions. The heat treatment resulted in the precipitation of nano-sized $\gamma \check{z}$ precipitates, which are of cuboidal form and oriented with edges parallel to the crystallographic directions. Moreover, they are often ordered into a three-dimensional grid. Mechanical properties of these materials depend strongly on the morphology of the precipitates and, thus, also on the applied heat treatment.

The microstructure of SC superalloys is conventionally studied by transmission electron microscopy (TEM). The advanced-material-characterization technique for SC superalloys involves small-angle neutron scattering (SANS), which yields bulk-averaged information on the parameters (precipitate shape, size, distance between the precipitates and volume fraction) of the microstructure.

\subsection{Gamma-prime rafting in SC superalloys}

Single-crystal nickel-based superalloys with a large fraction of hardening cuboidal gamma prime $\left(\gamma^{\prime}\right)$ (Figure 4), having a negative misfit if the creep is tested under a tensile load along the crystalline direction at a high temperature, can produce a lamellar $\gamma / \gamma^{\prime}$ pattern perpendicular to the loading axis. This drastic change in the morphology of $\gamma^{\prime}$ is called rafting. ${ }^{25}$ For a long creep life of a SC superalloy, it is important that the rafted $\gamma$, structure is stable. R. A. Mackay ${ }^{27}$ reported that directional coarsening of $\gamma^{\prime}$ began during the primary creep, under certain conditions (at $927-1038{ }^{\circ} \mathrm{C}$ ) and continued to develop after the onset of the steady-state creep. The length of the rafts increased linearly with the time, up to the plateau region. The thickness of the rafts, however, remained equal to the initial $\gamma^{\prime}$ size, at least up through the onset of the tertiary creep, which was reported to be a clear indication of the stability of the finely spaced $\gamma / \gamma$ '

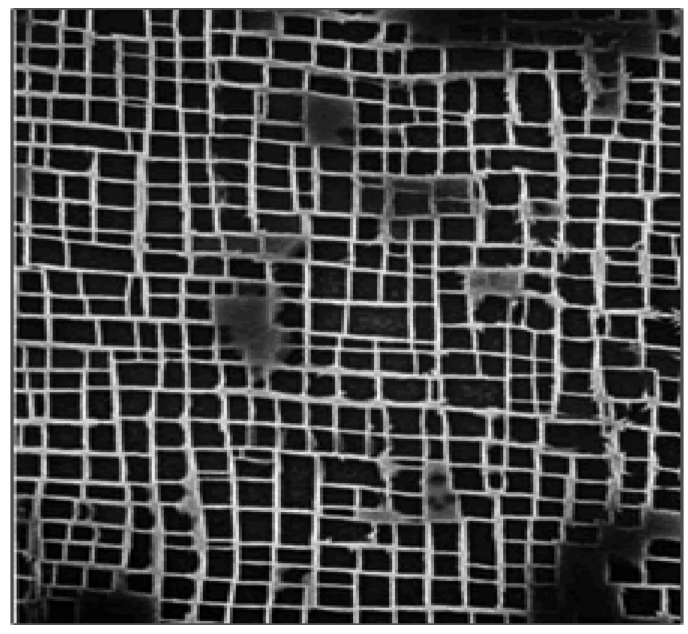

Figure 5: Microstructure of the SC superalloy developed by KEPCO$\mathrm{HITACHI}^{27}$

Slika 5: Mikrostruktura SC-superzlitine razvite pri KEPCO-HITA$\mathrm{CHI}^{27}$

lamellar structure. It was found that the single crystals with the finest $\gamma$ ' size exhibited the longest creep lives.

\subsection{Comparative analysis of energy-efficient SC super- alloys}

Recently, a new SC Ni-based superalloy has been jointly developed by the Kansai Electric Power Company, Co., Inc. (KEPCO), Nagoya Univ. and Hitachi, Ltd., Japan. ${ }^{28}$ This SC superalloy contains $\mathrm{Ni}, \mathrm{Co}, \mathrm{Cr}, \mathrm{W}$, $\mathrm{Al}, \mathrm{Ti}, \mathrm{Ta}, \mathrm{Re}, \mathrm{Hf}$, etc. and its microstructure is shown in Figure 5.

Figure 5 clearly shows the cuboidal morphology of the $\gamma^{\prime}$ precipitates (darker regions) in the $\gamma$ matrix (brighter regions) of the SC superalloy. Hashizume et al. reported $^{29}$ the size of the $\gamma^{\prime}$ precipitates to be around 0.4 $\mu \mathrm{m}$, which is a bit larger than the size reported for GTD-111 (Section 3.1). However, the significant beneficial aspect of the microstructure of KEPCO's SC superalloy, compared to GTD-111, is the absence of grain boundaries. Hence, the microstructure of KEPCO's SC superalloy (Figure 5) indicates its high-temperature creep strength, which is also confirmed by the high-temperature capability $\left(>1500{ }^{\circ} \mathrm{C}\right)$ of this superalloy. ${ }^{28}$ The chemical compositions of three SC blade superalloys (AM1, Rene-N6 and MC-534) are reported in Table 2.

Interesting common features of all the three SC alloys are high $\mathrm{W}, \mathrm{Al}$ and Ta contents (Table 2). Unique features of the MC-534 superalloy are its considerable $\mathrm{Re}$ and $\mathrm{Ru}$ contents, which impart a remarkable creep resistance to the alloy (Figure 6). Figure 6 shows the tensile-creep behavior of the three SC superalloys (AM1, René N6 and MC-534) at $760{ }^{\circ} \mathrm{C} / 840 \mathrm{MPa}$; all the three alloy specimens, tested at orientations within $5^{\circ}$ of the direction, ${ }^{30}$ are compared.

It is clearly evident from the creep curves in Figure 6 that the SC superalloy MC-534 has the lowest creep 


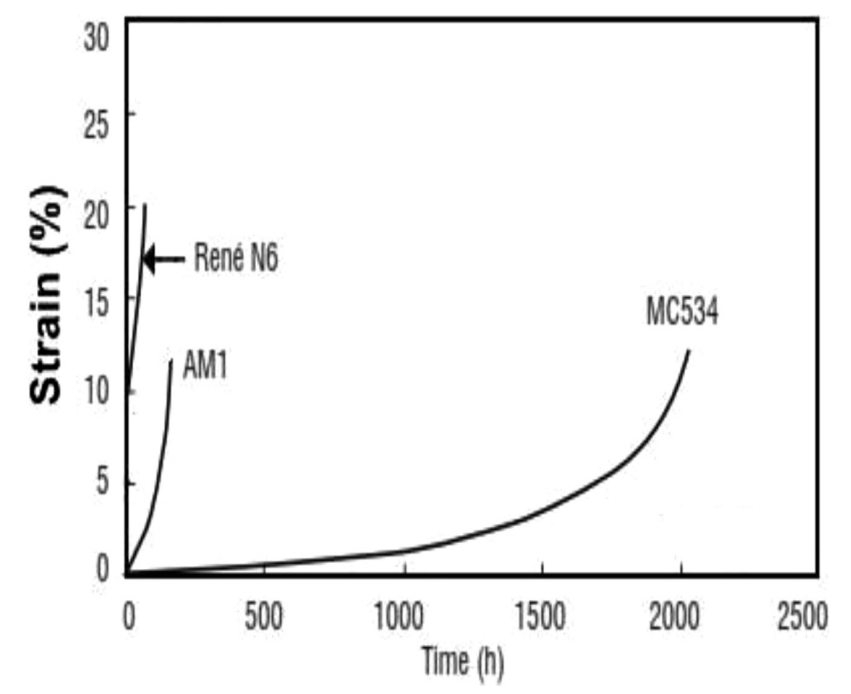

Figure 6: Creep curves at $760{ }^{\circ} \mathrm{C} / 840 \mathrm{MPa}$ for three typical SC superalloys

Slika 6: Krivulje lezenja pri $760{ }^{\circ} \mathrm{C} / 840 \mathrm{MPa}$ treh značilnih SC superzlitin

strain or deformation as compared to the other two SC alloys, attributed to the considerable $\mathrm{Re}$ and $\mathrm{Ru}$ contents (Table 3). However, the creep-rupture life of AM1 was reported to be ten times longer than that of the MC-534 alloy. ${ }^{14}$ Although both MA1 and MC-534 alloys have similar $\gamma / \gamma^{\prime}$ microstructures, they widely differ in their chemistries, $\gamma^{\prime}$-precipitate sizes and lattice mismatches. The pronounced and optimum creep-rupture life is observed at $760{ }^{\circ} \mathrm{C}$ and $840 \mathrm{MPa}$, which corresponds to the $\gamma$ '-precipitate size of $480 \mathrm{~nm}$. The low creep-rupture life of MC-534 can be explained owing to the presence of the deleterious $\delta$ phase in the microstructure of the alloy. Additionally, the excellent tensile-yield strength at 700 ${ }^{\circ} \mathrm{C}$ of the SC superalloy AM1, compared to the other competitive GT-blade superalloys, is remarkable (Table 2).

\section{FUTURE ALLOYS FOR HOTTER GTS}

A notable significant development in attaining the world's highest thermal efficiency of GT engines was reported (May, 2011) by Mitsubishi Heavy Industries, Ltd. (MHI), Japan, with respect to achieving the world's highest TIT of $1600{ }^{\circ} \mathrm{C}$ with the company's most advanced "J-Series" gas turbine, attaining a gross thermal efficiency of over $60 \%$ - the world's highest level in the CCGT applications. ${ }^{31}$ The most advanced J-Series GT uses a SC nickel-based superalloy.
Future GT manufacturers will demand alloys with an excellent high-temperature creep resistance, microstructural stability and castability, along with cost effectiveness. In view of the alloying of advanced SC superalloys with refractories and rare metals (e.g., Co, Cr, W, Ti, Ta, $\mathrm{Re}, \mathrm{Ru}, \mathrm{Hf}$, etc.) (Table 3), the cost of the production has risen significantly. This economic constraint requires research to produce future cost-effective superalloys without significantly sacrificing the long-life reliability. Reed et al. ${ }^{32}$ reported on alloy-design rules for the SC superalloys, which allow a very large composition range for just a few ideal compositions to render them cost effective. Another notable development in the production of cost-effective energy-efficient superalloys has recently been made by Hitachi Inc., who reported to reduce the material cost by $1 / 3$ of its previous level by reducing the use of rare metals and by adopting a unique manufacturing (casting) technology, without compromising the high-temperature strength, oxidation resistance, long service life and reliability even in the presence of polycrystalline regions, which form, with high probability, in SC superalloy blades.

The new trend of increasing the $\mathrm{Re}$ and $\mathrm{Ru}$ contents in recently developed $\mathrm{SC}$ alloys requires more research in view of both desirable and undesirable effects of the rare metals on the microstructure and creep behavior of the alloys. F. H. Latief and K. Kakehi ${ }^{34}$ reported the effects of the Re content and crystallographic orientation on the creep behavior of aluminized Ni-based SC superalloys. Although an addition of Re was found to be generally effective for the creep-strength improvement of the superalloys, the creep strength was significantly decreased in aluminized specimens due to the change in microstructure under the coating layer caused by the formation of the inter-diffusion zone (IDZ) and substratediffusion zone (SDZ). However, the specimens with the $\{100\}$ side surface showed longer creep-rupture lives than the specimens with the $\{110\}$ side surface, indicating an anisotropic creep behavior. ${ }^{34}$

A notable development for future superalloys was reported by the researchers, who proposed to control the $\mathrm{Cr}, \mathrm{Re}$, and $\mathrm{Ru}$ contents for enhancing the creep strength of the SC superalloys. ${ }^{35-36}$ An addition of $3 \%$ of the mass fraction of ruthenium $(\mathrm{Ru})$ was found to improve the intermediate temperature/intermediate stress-creep behaviors of the SC Ni-based superalloys; however, the high-temperature creep strength at the intermediate stress was not found to be good. ${ }^{35}$ The reduction in the $\gamma$ ' volume fraction upon the addition of $\mathrm{Ru}$ appears to be the principal cause of its diminishing strengthening con-

Table 3: Chemical compositions of typical SC superalloys $8,13,17,28$ Tabela 3: Kemijska sestava značilnih SC-superzlitin $8,13,17,28$

\begin{tabular}{|l|c|c|c|c|c|c|c|c|c|c|c|c|c|c|}
\hline \multicolumn{1}{|c|}{ Superalloy } & $\% \mathrm{Cr}$ & $\% \mathrm{Co}$ & $\% \mathrm{Ti}$ & $\% \mathrm{~W}$ & $\% \mathrm{Al}$ & $\% \mathrm{Ta}$ & $\% \mathrm{Mo}$ & $\% \mathrm{Fe}$ & $\% \mathrm{C}$ & $\% \mathrm{~B}$ & $\% \mathrm{Re}$ & $\% \mathrm{Ru}$ & $\% \mathrm{Hf}$ & $\% \mathrm{Ni}$ \\
\hline SC: AM1 & 7.8 & 6.5 & 1.1 & 5.7 & 5.2 & 7.9 & 2 & - & - & - & - & - & - & balance \\
\hline SC: René N6 & 4.5 & 12 & - & 5.7 & 6 & 7.5 & 1.1 & - & 0.05 & 0.04 & 5.3 & - & 0.15 & balance \\
\hline MC-534 & 4 & - & - & 5 & 5.8 & 6 & 4 & - & - & - & 3 & 4 & 0.1 & balance \\
\hline
\end{tabular}




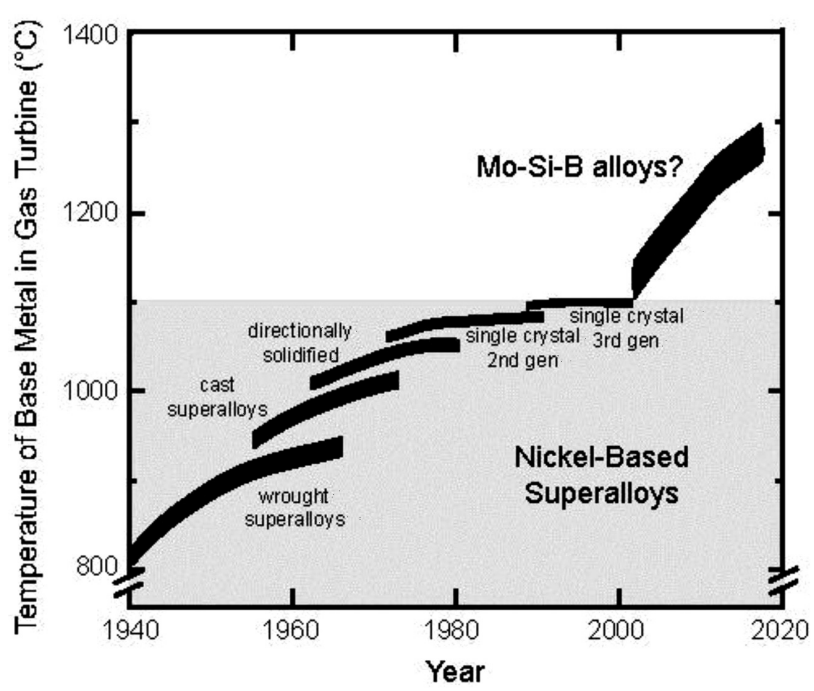

Figure 7: Plot showing the developments in temperature capabilities of superalloys

Slika 7: Diagram prikazuje napredek v temperaturnih zmogljivostih superzlitin

tribution at elevated temperatures. A.-C. Yeh et al. ${ }^{36}$ examined the microstructural stability and creep resistance of an advanced SC superalloy, which had high contents of $\mathrm{Cr}$ (4.6\% of mass fraction), Re (6.4\% of mass fraction) and $\mathrm{Ru}(5.0 \%$ of mass fraction).

Experimental results showed that high $\mathrm{Re}+\mathrm{Ru}$ contents could promote the formation of the hexagonal $\delta$ phase at $900{ }^{\circ} \mathrm{C}$; additional $\mathrm{Cr}$ and $\mathrm{Re}$ could enhance the precipitation of the TCP phase at $1100{ }^{\circ} \mathrm{C}$. Although an increase in the lattice misfit between $\gamma$ and $\gamma^{\prime}$ in the investigated SC superalloy could strengthen the alloy against the creep deformation due to high temperatures $\left(\geq 1000{ }^{\circ} \mathrm{C}\right)$ and low stresses $(\leq 245 \mathrm{MPa})$, the microstructural stability remained the same. The tendency to raft should be avoided during the creep at lower temperatures and higher stresses. ${ }^{36}$

Although the advanced alloys used in modern GTs are nickel-based, the tremendous research on the energy-efficient GTs operating at higher TITs $(>1,600$ $\left.{ }^{\circ} \mathrm{C}\right)$ requires the development of new alloys with greater temperature capabilities for future applications. These new alloys should be based on metals with higher melting temperatures (e.g., molybdenum (Mo) and columbium $(\mathrm{Cb})$ alloyed with silicon) that can be prospective candidates for hotter GT engines. ${ }^{8}$ This future trend is also evident in Figure 7, which illustrates the development of advanced superalloys with respect to the temperature capacity of the alloys since 1940.

Figure 7 not only focuses on nickel-based superalloys for gas-turbine engine applications, but also demonstrates the need for developing new energy-efficient superalloys, such as Mo-based superalloys for achieving further technological gains.

\section{CONCLUSIONS AND RECOMMENDATIONS}

Having reviewed the recent advances in the GT-blade-material technology, it is recommended to integrate the latest efficiency-improvement techniques with the advanced superalloy technologies to enhance the efficiency and power output in modern industrial gas turbines. Recently developed equiaxed superalloys (e.g., Allvac ${ }^{\circledR} 718$ Plus, GTD-111, etc.) and various SC alloys (with high $\mathrm{Re}, \mathrm{Ru}$ and $\mathrm{Cr}$ contents) should be comparatively analyzed and selected for the hot-section component of a modern GT engine, with the aid of the data presented in the paper. In view of the latest development in the GT technology, which enables an operation at $\mathrm{TIT}=1600{ }^{\circ} \mathrm{C}$, it is recommended to develop superalloys based on higher melting temperatures (such as molybdenum-based superalloys) for future CCGT plants with a possibility of operating at TIT $>1600{ }^{\circ} \mathrm{C}$.

\section{REFERENCES}

${ }^{1}$ I. G. Wright, T. B. Gibbons, Recent Developments in Gas Turbine Materials and Technology and Their Implications for Syngas Firing, International Journal of Hydrogen Energy, (2007) 32, 3610-3621, doi:10.1016/j.ijhydene.2006.08.049

${ }^{2}$ P. Jansohn (Ed.), Modern Gas Turbine Systems, $1^{\text {st }}$ Ed., Woodhead Publishing, 2013, 44

${ }^{3}$ C. Kim, Creep damage characterization of Ni-based superalloy by acoustic nonlinearity, Progress in Natural Science Materials International, 22 (2012) 4, 303-310, doi:10.1016/j.pnsc.2012.07.005

${ }^{4}$ G. Stein-Brzozowska, D. M. Flórez, J. Maier, G. Scheffknecht, Nickel-base superalloys for ultra-supercritical coal-fired power plants: fireside corrosion, Laboratory studies and power plant exposures, Fuel, 108 (2013) 6, 521-533 doi:10.1016/j.fuel.2012.11.081

${ }^{5}$ Z. Huda, T. Zaharinie, S. H. Islam, Effects of annealing parameters on grain growth behavior of Haynes 718 superalloy, International Journal of Physical Science, 30 (2011) 6, 7073-7077, doi:10.5897/ IJPS11.245

${ }^{6}$ Y. Xingfu, T. Sugui, W. Minggang, Z. Shu, L. Xudong, C. Shusen, Creep behaviors and effect factors of single crystal nickel-base superalloys, Materials Science and Engineering A, 499 (2009) 1-2, 352-359, doi:10.1016/j.msea.2008.09.038

${ }^{7} \mathrm{Z}$. Huda, Influence of particle mechanisms on the kinetics of grain growth in a P/M superalloy, Materials Science Forum, 467 (2004), 986-990, doi:scientific.net/MSF.467-470.985

${ }^{8}$ W. Maktouf, K. Sai, An investigation of premature fatigue failures of gas turbine blade, Engineering Failure Analysis, 47 Part A, (2015) 89-101, doi:10.1016/j.engfailanal.2014.09.015

${ }^{9}$ J. H. Perepezko, The Hotter the Engine, the Better, Science, 326 (2009) 5956, 1068-1069, doi:10.1126/science. 1179327 (http://science.sciencemag.org/content/326/5956/1068)

${ }^{10} \mathrm{Z}$. Huda, Development of design principles for a creep-limited alloy for turbine blades, Journal of Materials Engineering and Performance, ASM International, 4 (1995) 1, 48-53 http://link.springer.com/article/10.1007\%2FBF02682704

${ }^{11} \mathrm{G}$. Jianting, The current situation of the application and development of superalloys in the field of energy industry, Acta Metallurgica Sinica, 46 (2011) 5, 513-527, doi:10.3724/SP.J.1037.2009.00860 http://www.ams.org.cn/EN/abstract/abstract18812.shtml

${ }^{12}$ R. C. Reed, The Superalloys: Fundamentals and Applications, 2006, Cambridge University Press, UK, 2006

${ }^{13} \mathrm{Z}$. Huda, Development of heat treatment process for a P/M superalloy for turbine blades, Materials and Design, 28 (2007) 5, 1664 -1667 doi:10.1016/j.matdes.2006.03.026 


\section{Z. HUDA: ENERGY-EFFICIENT GAS-TURBINE BLADE-MATERIAL TECHNOLOGY - A REVIEW}

${ }^{14}$ P. Caron, O. Lavigne, Recent studies at Onera on superalloys for single-crystal turbine blades, The Onera Journal - Aerospace Lab, 3 (2011), 1-14 http://www.aerospacelab-journal.org/al3

${ }^{15}$ S. A. Sajjadi, S. Nategh, A high temperature deformation mechanism map for the high performance Ni-base superalloy GTD-111, Materials Science and Engineering A, 307 (2001) 1-2, 158-164, doi:10.1016/S0921-5093(00)01822-0

${ }^{16}$ S. A. Sajjadi, S. Nategh, R. I. L. Guthrie, Study of microstructure and mechanical properties of high performance Ni-base superalloy GTD-111, Materials Science and Engineering A, 325 (2002), 484-489, doi:10.1016/S0921-5093(01)01709-9

${ }^{17}$ S. A. Sajjadi, S. M. Zebarjad, R. I. L. Guthrie, M. Isac, Microstructure evolution of high-performance Ni-base superalloy GTD-111 with heat treatment parameters, Journal of Materials Processing Technology, 175 (2006) 1-3, 376-381 http://www.journalamme.org/ papers_amme03/12157.pdf

${ }^{18}$ G. A. Zickler, R. Schnitzer, R. Radis, R. Hochfellner, R. Schweins, M. Stockinger, H. Leitner, Microstructure and mechanical properties of the superalloy ATI Allvac ${ }^{\circledR} 718$ Plus $^{\mathrm{TM}}$, Materials Science and Engineering A, 523 (2009) 1-2, 295-303, doi:10.1016/j.msea. 2009.06.014

${ }^{19}$ P. W. Schilke, Advanced Gas Turbine Materials and Coatings, GE Energy, NY, USA, 1995 https://powergen.gepower.com/content/dam/ gepowerpgdp/global/en_US/documents/technical/ger/ger-3569g-adv anced-gas-turbine-materials-coatings.pdf

${ }^{20} \mathrm{Z}$. Huda, Recent advances in energy materials for hot sections of modern gas turbine engines, Proc. ICMME-2012: International Conference on Mechanical and Materials Engineering, held 19-21 Feb, 2012 at Kuala Lumpur, Malaysia, Org. by World Academy of Science, Engineering \& Tech., USA, 62, 781-783 http://waset.org/ publications/5314/recent-advances-in-energy-materials-for-hotsections-of-modern-gas-turbine-engines

${ }^{21}$ H. M. Tawancy, A. I. Mohammad, L. M. Al-Hadhrami, H. Dafalla, F. K. Alyousf, On the performance and failure mechanism of thermal barrier coating systems used in gas turbine blade applications: Influence of bond coat/superalloy combination, Engineering Failure Analysis, 57 (2015) 1-20, doi:10.1016/j.engfailanal.2015.07.023

${ }^{22}$ R. Kitazawa, M. Tanaka, Y. Kagawa, Y. F. Liu, Damage evolution of TBC system under in-phase thermo-mechanical tests, Materials Science and Engineering B, 173 (2010) 1-3, 130-134, doi:10.1016/ j.mseb.2009.12.022

${ }^{23}$ SIEMENS Inc., Materials for the Environment - Optimizing Turbine Blades, 2007 (online: http://www.siemens.com/innovation/en/publikation en/publications_pof/pof_fall_2007/materials_for_the_environment/optimizing_turbine_blades.htm)

${ }^{24}$ S. A. Sajjadi, S. M. Zebarjad, Study of fracture mechanism of a nickel-base superalloy at different temperatures, Journal of Achievements in Materials and Manufacturing Engineering, 18 (2006) 1-2, 227-230 http://www.journalamme.org/papers_amme06/1247.pdf

${ }^{25}$ R. L. Kennedy, ALLVAC@ ${ }^{1}$ 18PLUS ${ }^{\mathrm{TM}}$ superalloy for the next forty years, in "Superalloys 718, 625, 706 and Derivatives 2005", Edited by E. A. Loria, Publisher: TMS (The Minerals, Metals \& Materials Society), USA, 2005 http://www.tms.org/superalloys/10.7449/ 2005/superalloys_2005_1_14.pdf

${ }^{26}$ N. Tsuno, A. Sato, K. Tanaka, H. Inui, Evolution of raft structure during creep deformation of Ni-based single-crystal superalloy TMS-138, Advanced Materials Research, 278 (2011), 19-24, doi:10.4028/www.scientific.net/AMR.278.19 http://www.scientific. net/AMR.278.19

${ }^{27}$ R. A. Mackay, Morphological changes of gamma prime precipitates in nickel-base superalloy single crystals, NTRS (NASA Technical Report Server) \# 8/1984, 1984, (Retrieved from online: https://www.researchgate.net/publication/24153495 on February 18, 2016)

${ }^{28}$ R. Hashizume, A. Yoshinari, T. Kiyono, Y. Murata, M. Morinaga, Development of Ni-base SC superalloys for power generation gas turbines, Energy Materials, 2 (2007) 1, 5-12 http://www.maneyonline.com/doi/abs/10.1179/174892406X198128

${ }^{29}$ R. Hashizume, A. Yoshinari, T. Kiyono, Y. Murata, M. Morinaga, Development of Ni-base single crystal superalloys for power generation gas turbines, in Superalloys 2004 (Edited by K. A Green, T. M. Pollok, H. Harada, T. E Howson, R. C. Reed, J. J. Schirra, S. Walston), Publisher: TMS (The Minerals, Metals \& Materials Society), 2004

${ }^{30}$ F. Diologent, P. Caron, On the creep behavior at $1033 \mathrm{~K}$ of new generation single-crystal superalloys, Materials Science and Engineering A, 385 (2004) 1-2, 245-257, doi:10.1016/j.msea.2004. 07.016

${ }^{31} \mathrm{MHI}$ (Mitsubishi Heavy Industries), MHI achieves $1,600^{\circ} \mathrm{C}$ turbine inlet temperature in test operation of world's highest thermal efficiency "J-Series" gas turbine, MHI News, May 26, 2011, No. 1435 http://www.mhi.co.jp/en/news/story/1105261435.html

${ }^{32}$ R. C. Reed, N. Tao, N. Warnken, Alloy-By-Design: Application to nickel-base single crystal superalloys, Acta Materialia, 57 (2009) 19, 5898-5913, doi:10.1016/j.actamat.2009.08.018

${ }^{33}$ Hitachi Technology, 2009-2010, Materials, Components and Others, 69-70 http://www.hitachi.com/rev/archive/2009/_icsFiles/afieldfile/ 2011/12/05/r2009_technology_mc.pdf

${ }^{34}$ F. H. Latief, K. Kakehi, Effects of Re content and crystallographic orientation on creep behavior of aluminized Ni-base single crystal superalloys, Materials and Design, 49 (2013), 485-492, doi:10.1016/ j.matdes.2013.01.022

${ }^{35}$ R. A. Hobbs, L. Zhang, C. M. F. Rae, S. Tin, The effect of ruthenium on the intermediate to high temperature creep response of high refractory content single crystal nickel-base superalloys, Materials Science and Engineering A, 489 (2008) 1-2, 65-76, doi:10.1016/ j.msea.2007.12.045

${ }^{36}$ A-C. Yeh, A. Sato, T. Kobayashi, H. Harada, On the creep and phase stability of advanced Ni-base single-crystal superalloys, Materials Science and Engineering, 490 (2008) 1-2, 445-451, doi:10.1016/j.msea.2008.02.008 